\title{
New record of Bassaricyon medius in the Colombian Caribbean
}

\author{
Julio Chacón-Pacheco ${ }^{1,} 2^{*}$, Duván J. Bassa-Hernández ${ }^{1}$, Héctor E. Ramírez-Chaves ${ }^{3}$ \\ 1Grupo de Investigación Biodiversidad Unicórdoba, Facultad de Ciencias Básicas, Universidad de Córdoba, Carrera 6 No. 76-103, \\ Montería. Córdoba, Colombia. Email: jchacon bio@hotmail.com (JCh), duvanjbh@hotmail.com (DBH) \\ ${ }^{2}$ Grupo de Investigación AMDAC, Institución Educativa José María Córdoba. Calle 29 No 16b-43 Barrio San José, CP. 230002, \\ Montería. Córdoba, Colombia. \\ ${ }^{3}$ Departamento de Ciencias Biológicas, Facultad de Ciencias Exactas y Naturales, Universidad de Caldas, Manizales. Caldas, \\ Colombia. Email: hector.ramirez@ucaldas.edu.co (HRC) \\ *Corresponding author
}

\begin{abstract}
Bassaricyon medius is a medium-sized olingo that inhabits in forested areas from central Panama to west of the Andes of Colombia and Ecuador. The species was described based on a specimen from the Colombian Chocó. However, it has been little studied at a national scale. In Colombia, the species is currently known only from the Andean and Pacific regions. We document a new record of $B$. medius from the Caribbean region of Colombia, representing both a geographic and an ecological extension into the dry forest of northern Colombia. To update the distribution, we searched for historical records in the literature, collection vouchers, and databases. The new record is based on photographs on a live adult female B. medius and the skull of the same specimen deposited in the zoological collection of the University of Cordoba. We provide cranial and external morphometric data from the specimen, and we compare this information with morphological descriptions of previous records from Colombia in literature. The new record comes from the area around Sierra Chiquita, Department of Córdoba, and increases the distribution range into the dry forest of northern Colombia. We compiled 18 historical records of the species in the country, all form the Andean and Pacific regions. This record confirms the presence of $B$. medius in the Colombian Caribbean, updating the known distribution of the species in Colombia that currently includes the departments of Antioquia, Cauca, Chocó, Córdoba, Nariño, and Valle del Cauca.
\end{abstract}

Bassaricyon medius es un olingo de tamaño medio que habita en áreas selváticas desde el centro de Panamá hasta el oeste de los Andes de Colombia y Ecuador. Esta especie fue descrita a partir de un ejemplar procedente del Chocó de Colombia. Sin embargo, ha sido poco estudiada a escala nacional. En Colombia, la especie es conocida únicamente de registros provenientes de las regiones Andina y Pacífica. Documentamos un nuevo registro de B. medius en la región Caribe de Colombia, que representa una extensión geográfica y ecológica de la especie en los bosques secos del norte de Colombia. Para actualizar la distribución, buscamos registros históricos en la bibliografía, ejemplares de colección y bases de datos. El registro se basa en fotografías de un ejemplar vivo hembra adulta de B. medius y el cráneo del mismo ejemplar depositado en la Colección Zoológica de la Universidad de Córdoba. Del registro proveemos información morfométrica craneal y externa y comparamos esta información con las descripciones morfológicas de registros previos de Colombia en la literatura. El nuevo registro proviene de los alrededores de Sierra Chiquita en el departamento de Córdoba, que extiende la distribución de la especie en los bosques secos del norte de Colombia. Compilamos 18 registros históricos de la especie en el país, todos de las regiones Andina y Pacífica. Este registro confirma la presencia de $B$. medius para el Caribe colombiano, permitiendo actualizar la distribución de la especie en Colombia que actualmente cuenta con registros para los departamentos de Antioquia, Cauca, Chocó, Córdoba, Nariño y Valle del Cauca.

Keywords: Andes; Chocó; Procyonidae; range extension; threats.

(c) 2019 Asociación Mexicana de Mastozoología, www.mastozoologiamexicana.org

\section{Introduction}

Procyonids (Procyonidae) are a group of carnivore mammals (Carnivora) from the Americas. Among procyonids, the genus Bassaricyon comprises four species (Helgen et al. 2013) distributed from Central America south to southern Bolivia in South America (Emmons and Feer 1990; GonzálezMaya and Belant 2010), in an elevational range between 0 and $2,750 \mathrm{~m}$. Procyonids live in tropical, subtropical, dry and montane forests (Helgen et al. 2013). Due to their cryptic nature and solitary arboreal habits, field sightings are rare, hence limiting the current knowledge on these species (Reid 1998; Ramirez and Valencia 2007; González-Maya and Belant 2010).

In Colombia, the knowledge of procyonids has increased in recent years, including the number of species reported from seven (Guzmán-Lenis 2004; Solari et al. 2013) to nine (Andrade-Ponce et al. 2016). This increase is based on the record of one recently described species (B. neblina) and the knowledge on the distribution of the genus (Helgen et al. 2013). Before the work of Helgen et al. (2013) that elucidated the richness of this genus in the Neotropic, information on this genus was scarce. Today, three species of Bassaricyon are recorded for Colombia (B. alleni, B. medius and $B$. neblina), with recent studies on the distribution only for B. neblina and B. alleni (Suárez-Castro and Ramírez-Chaves 2015; Andrade-Ponce et al. 2015, 2016; Cardona et al. 2016; Gerstner et al. 2018).

Bassaricyon medius was described from a single specimen from Jiménez (731 masl elevation) in the Department of Chocó, Colombia (Helgen et al. 2013; Andrade-Ponce et al. 2016). Additional information of this species is limited to few records on distribution and morphology (Thomas 1909; Goldman 1912; Saavedra-Rodríguez and VelandiaPerilla 2011; Helgen et al. 2013; Andrade-Ponce et al. 2016). 
B. medius is a medium-sized procyonid (total length: 680 to $905 \mathrm{~mm}$ ) relative to the other species in the genus (Helgen et al. 2013). B. medius resembles B. alleni in pelage, but the latter is characterized by a more uniform coloration from head to tail, with a darker dorsal stripe (Helgen et al. 2013). The nose pigmentation is a feature useful for differentiating the species of Bassaricyon. B. medius has a typically pink nose (although the photographs of live specimens in Helgen et al. 2013 show dark brown colorations), differing from that of $B$. alleni, which has a darker pigmentation (Helgen et al. 2013). Another distinctive character between species is the size of the fourth lower premolar, typically smaller in B. medius (although the mean values, standard deviation, and ranges in Helgen et al. 2013 do not support relevant differences).

Bassaricyon medius is distributed in Colombia, in the Chocó-Darién, Magdalena, and Cauca biogeographic provinces (Andrade-Ponce et al. 2016), in the Departments of Antioquia, Chocó, Cauca, Nariño, and Valle del Cauca (Saavedra-Rodríguez and Velandia-Perilla 2011; Helgen et al. 2013; Andrade-Ponce et al. 2016), but its presence in the Caribbean Region had not been previously recorded (e. g., Muñoz-S and Hoyos-R 2012; Diaz-Pulido et al. 2014; RaceroCasarrubia et al. 2015). B. medius includes two subspecies: B. m. medius and B. m. orinomus, which differ mainly in body size (total length: 680 to 819 vs. 770 to $905 \mathrm{~mm}$, respectively, Helgen et al. 2013). In this study, we recorded the presence of Bassaricyon medius in the Peri-Caribbean Arid Belt Biogeographical Province, Colombian Caribbean.

\section{Materials and Methods}

The new record of $B$. medius comes from the Colombian Caribbean and it is based on photographs of a single live adult female (Figure 1), and the preserved skull of the same specimen (Figure 2). The photographs supplementing this record (Figure 1) were donated by members of the Urbanización Los Recuerdos community, municipality of Monteria, Department of Córdoba. The specimen was delivered

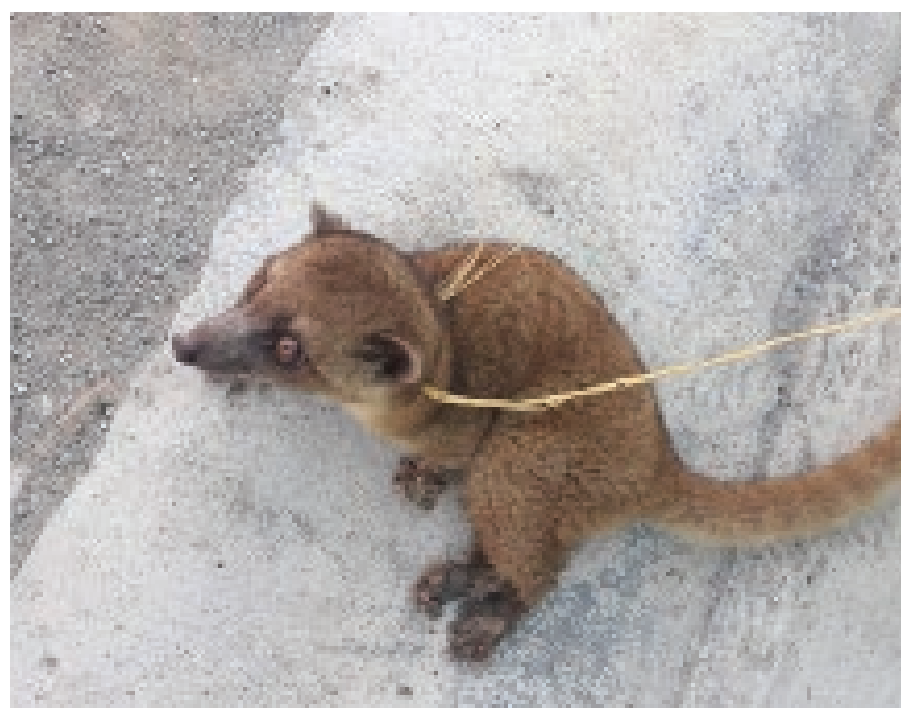

Figure 1. Adult female of Bassaricyon medius captured by inhabitants of urbanización El Recuerdo, Montería, Córdoba. The specimen was delivered to members of the Biodiversidad Unicórdoba Research Group.

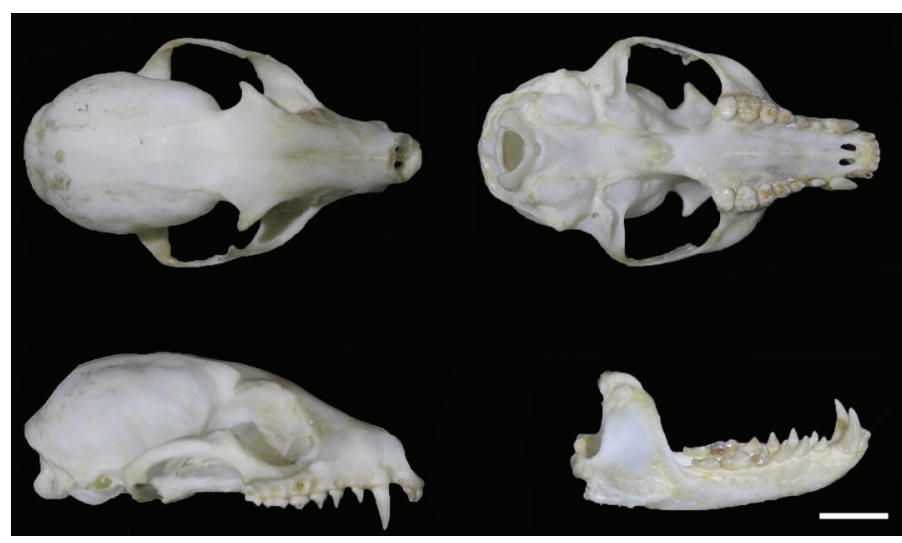

Figure 2. Skull of an adult female Bassaricyon medius (CZUC-M 0246) from the Municipality of Monteria, Department of Córdoba, Colombia. Scale $=15.0 \mathrm{~mm}$.

dead, in a state of decomposition, and with all four limbs fractured, to members of the Biodiversidad Unicordoba Research Group. We recorded external measurements (total length, head-body length, tail length, and hindfoot length; Table 1), and only the skull could be rescued, which was deposited in the collection of Zoology at the University of Córdoba (CZUC-M-0246; Figure 2). Based on the photographs of the live specimen (Figure 1), we noted distinctive external characters supporting the taxonomic identification (Helgen et al. 2013). These include a uniform coloration between the tail and the body, lacking a blackish dorsal stripe and the coloration of the nose (dark brown, as it appears in the live specimens in Helgen et al. 2013). To confirm the identification, we also took the following cranial measurements recorded in the revision of the genus (Helgen et al. 2013): condylobasal length (CBL), zygomatic width (ZYG), cranial vault height (BBC), cranial vault width (HBC), upper dental series (MTR), width between canines (CC), greatest width across the postdental palatal shelf (WPP), postdental palate length (LPP), anteroposterior length of the auditory bulla (LAB), and inner dorsoventral diameter of the external auditory meatus (EAM). The localities reported for the species were surveyed in the literature (e. g., Thomas 1909; Goldman 1912; Rivas-Pava et al. 2007; Saavedra-Rodríguez and Velandia-Perilla 2011; Helgen et al. 2013; Andrade-Ponce et al. 2016) and in databases of national and foreign museums.

\section{Results}

The new record of $B$. medius comes from an urban matrix of the municipality of Monteria (Department of Córdoba), at Urbanización Los Recuerdos ( $8^{\circ} 43^{\prime} 08.1^{\prime \prime} \quad \mathrm{N},-75^{\circ} 53^{\prime}$ 23.3"W; 14 masl), next to tropical dry forest patches associated with Sierra Chiquita, and was obtained on 4 November 2017 (Figure 3). Sierra Chiquita is a short range of hills belonging to the foothills of Serrania de San Jerónimo, located in the middle portion of the Sinú river valley, Córdoba. This area has a mean annual rainfall of approximately $1,035 \mathrm{~mm}$, mean annual temperature of $27.1^{\circ} \mathrm{C}$, and mean relative humidity of $84 \%$ (Arteaga 2014). The individual was captured on typical trees of the tropical dry forest biome, within an agricultural system associated with Sierra 


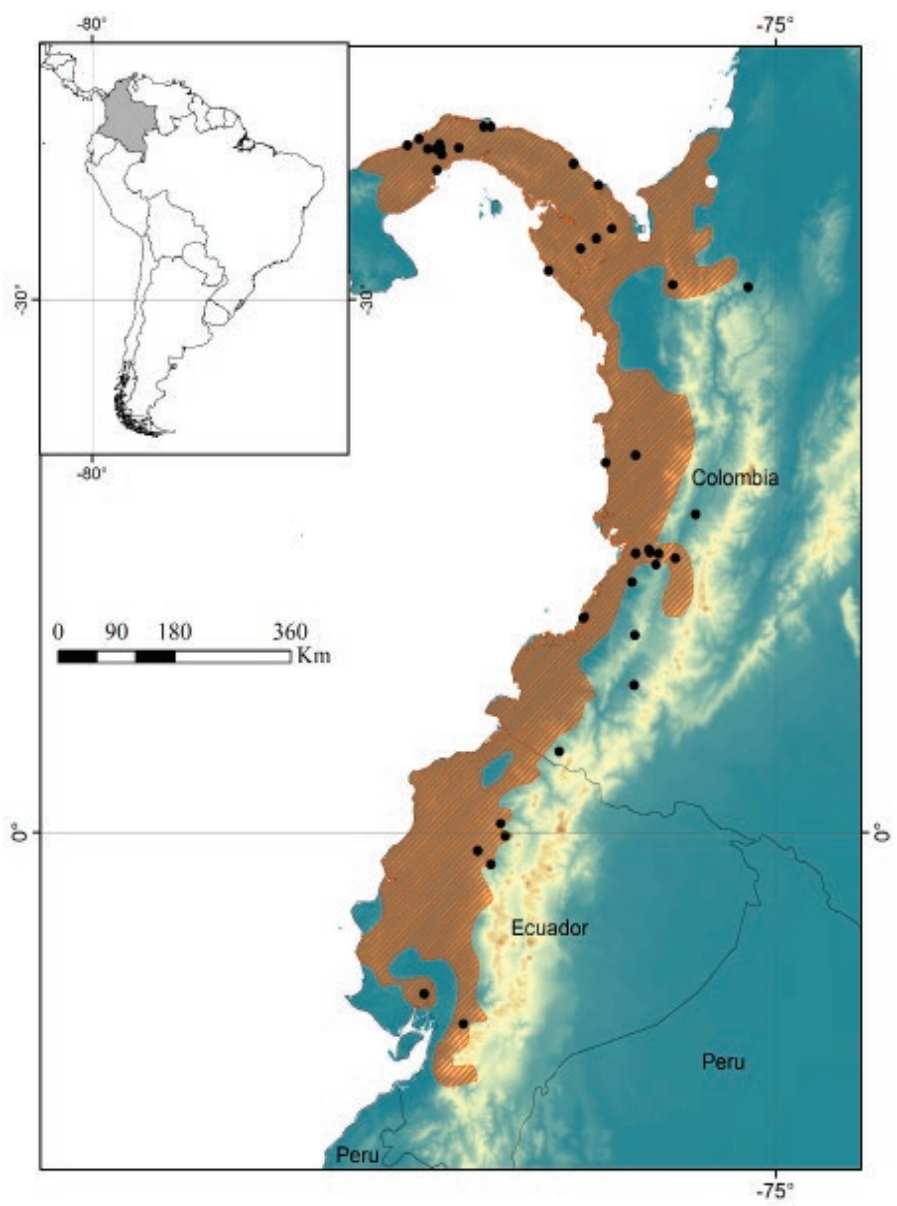

Figure 3. Confirmed records of Bassaricyon medius. White circle: new record in the Department of Córdoba, Colombia. Black circles: confirmed records. Orange: potential distribution range according to IUCN (Helgen et al. 2016).

Chiquita, by members of the community of urbanización El Recuerdo who allegedly intended to market the specimen using social networks.

Externally, the specimen shows a uniform coloration between the body and the tail, with no evidence of a dark dorsal strip (Figure 1). The nose is dark brown. The external measures are similar to those observed in other species of the genus (Table 1); however, total length and tail length ( 860.0 and $460.0 \mathrm{~mm}$ respectively) exceed the values seen in B. neblina (upper limits: 820.0 and $424.0 \mathrm{~mm}$, respectively). The skull measurements are similar to those recorded for females of other species in the genus found in Colombia (Table 1). However, condylobasal length (82.0 $\mathrm{mm})$ and cranial vault width $(28.2 \mathrm{~mm}$ ) exceed the upper limits observed in B. alleni and B. neblina $(80.5$ and $28.1 \mathrm{~mm}$ for B. alleni, and 77.9 and $27.8 \mathrm{~mm}$ for B. neblina).

When we compared the pelage coloration and external and cranial metrics of the specimen CZUC-M-0246 with those reported in the literature (Figures 1, 2; Table 1). We found that they match those reported for B. medius ( $\mathrm{Hel}-$ gen et al. 2013). B. medius and B. alleni are closely similar; however, CZUC-M-0246 was identified based on external and cranial traits of B. medius, namely slightly lighter coloration of the dorsal pelage, smaller body size, and wider and shorter rostrum. Based on body size and craniodental char-
Table 1. External and cranial measurements ( $\mathrm{n}$ in bold) of species of Bassaricyon (Helgen et al. 2013). Numbers are mean \pm standard deviation, with ranges in parentheses.

\begin{tabular}{|c|c|c|c|c|}
\hline Measurements & CZUC-M-0246 & $\begin{array}{c}\text { B. medius medius } \\
n=12 ; n=7\end{array}$ & $\begin{array}{l}\text { B. medius orinomus } \\
n=24 ; n=17\end{array}$ & $\begin{array}{c}\text { B. } \text { alleni } \\
n=27 ; n=17 \text { 우 }\end{array}$ \\
\hline TL & 860.00 & $\begin{array}{c}754.00 \pm 49.70 \\
(680.00-819.00)\end{array}$ & $\begin{array}{c}844.00 \pm 42.90 \\
(770.00-905.00)\end{array}$ & $\begin{array}{c}842.00 \pm 50.60 \\
(705.00-985.00)\end{array}$ \\
\hline $\mathrm{HB}$ & 400.00 & $\begin{array}{c}362.00 \pm 29.50 \\
(310.00-415.00)\end{array}$ & $\begin{array}{c}385.00 \pm 17.20 \\
(355.00-410.00)\end{array}$ & $\begin{array}{c}391.00 \pm 29.30 \\
(304.00-455.00)\end{array}$ \\
\hline Tail & 460.00 & $\begin{array}{c}392.00 \pm 29.10 \\
(350.00-435.00)\end{array}$ & $\begin{array}{c}460.00 \pm 33.60 \\
(400.00-520.00)\end{array}$ & $\begin{array}{c}450.00 \pm 28.80 \\
(401.00-530.00)\end{array}$ \\
\hline $\mathrm{HF}$ & 82.00 & $\begin{array}{c}73.00 \pm 5.40 \\
(58.00-79.00)\end{array}$ & $\begin{array}{c}85.00 \pm 3.50 \\
(77.00-92.00)\end{array}$ & $\begin{array}{c}81.00 \pm 5.80 \\
(70.00-92.00)\end{array}$ \\
\hline Tail/HB & 1.15 & $\begin{array}{l}1.10 \pm 0.09 \\
(0.97-1.24)\end{array}$ & $\begin{array}{l}1.20 \pm 0.08 \\
(1.04-1.35)\end{array}$ & $\begin{array}{l}1.15 \pm 0.08 \\
(1.00-1.30)\end{array}$ \\
\hline CBL & 82.00 & $\begin{array}{c}75.40 \pm 1.65 \\
(72.40-76.70)\end{array}$ & $\begin{array}{c}78.80 \pm 1.72 \\
(75.50-82.30)\end{array}$ & $\begin{array}{c}77.00 \pm 2.24 \\
(73.10-80.50)\end{array}$ \\
\hline ZYG & 48.60 & $\begin{array}{c}48.50 \pm 1.69 \\
(46.50-51.00)\end{array}$ & $\begin{array}{c}51.20 \pm 1.98 \\
(47.40-54.00)\end{array}$ & $\begin{array}{c}50.20 \pm 0.99 \\
(48.60-52.20)\end{array}$ \\
\hline BBC & 34.27 & $\begin{array}{c}34.40 \pm 0.41 \\
(33.70-35.00)\end{array}$ & $\begin{array}{c}35.00 \pm 1.15 \\
(32.80-37.20)\end{array}$ & $\begin{array}{c}34.90 \pm 0.91 \\
(33.30-36.80)\end{array}$ \\
\hline $\mathrm{HBC}$ & 28.25 & $\begin{array}{c}26.80 \pm 0.89 \\
(26.10-28.50)\end{array}$ & $\begin{array}{c}27.00 \pm 0.89 \\
(25.40-28.50)\end{array}$ & $\begin{array}{c}26.90 \pm 0.63 \\
(26.00-28.10)\end{array}$ \\
\hline MTR & 26.00 & $\begin{array}{c}27.10 \pm 0.78 \\
(25.60-27.90)\end{array}$ & $\begin{array}{c}28.00 \pm 0.77 \\
(26.40-29.10)\end{array}$ & $\begin{array}{c}27.30 \pm 0.69 \\
(26.10-28.50)\end{array}$ \\
\hline $\mathrm{CC}$ & 15.00 & $\begin{array}{c}15.00 \pm 0.46 \\
(14.50-15.80)\end{array}$ & $\begin{array}{c}16.10 \pm 0.71 \\
(14.60-17.20)\end{array}$ & $\begin{array}{c}15.90 \pm 0.55 \\
(14.80-16.80)\end{array}$ \\
\hline WPP & 9.20 & $\begin{array}{l}10.00 \pm 0.57 \\
(9.10-10.60)\end{array}$ & $\begin{array}{l}10.30 \pm 1.04 \\
(9.00-13.00)\end{array}$ & $\begin{array}{c}9.90 \pm 0.89 \\
(8.20-11.70)\end{array}$ \\
\hline LPP & 10.90 & $\begin{array}{c}9.80 \pm 0.84 \\
(8.90-11.30)\end{array}$ & $\begin{array}{l}10.20 \pm 1.01 \\
(8.10-11.80)\end{array}$ & $\begin{array}{l}10.40 \pm 0.67 \\
(8.70-11.60)\end{array}$ \\
\hline$L A B$ & 12.40 & $\begin{array}{c}13.40 \pm 0.45 \\
(12.60-13.90)\end{array}$ & $\begin{array}{c}14.30 \pm 0.73 \\
(12.80-15.20)\end{array}$ & $\begin{array}{c}14.40 \pm 0.81 \\
(13.00-15.60)\end{array}$ \\
\hline EAM & 3.90 & $\begin{array}{l}3.90 \pm 0.34 \\
(3.50-4.40)\end{array}$ & $\begin{array}{l}3.90 \pm 0.28 \\
(3.60-4.70)\end{array}$ & $\begin{array}{l}3.80 \pm 0.36 \\
(3.20-4.40)\end{array}$ \\
\hline
\end{tabular}

acters, mainly condylobasal length (Table 1 ), this individual was assigned to B. m. orinomus (CBL: 72 to $76.7 \mathrm{~mm}$ in B. $m$. medius vs. 75.5 to $82.3 \mathrm{~mm}$ in females of $B$. $m$. orinomus).

\section{Discussion}

Over the past 10 years, studies on mammals of the Department of Cordoba increased the knowledge of species living in the different subregions across the territory (RaceroCasarrubia et al. 2015). For Procyonidae, only two species (Potos flavus and Procyon cancrivorus) were previously reported in several localities of the Department (Solari et al. 2013; Racero-Casarrubia et al. 2015). Thus, this is the first record of Bassaricyon in Córdoba. The lack of previous records of Bassaricyon in Córdoba may derive from the fact that these procyonids can easily be misidentified with the kinkajou (Potos flavus), which is more common in the Caribbean region of Colombia (Suárez-Castro and RamírezChaves 2015).

This new record of $B$. medius adds to the localities reported in the literature for is the northern-most known locality of the species in Colombia (Thomas 1909; Gold- 
man 1912; Saavedra-Rodríguez and Velandia-Perilla 2011; Helgen et al. 2013; Andrade-Ponce et al. 2016), which now has records for the Caribbean, Pacific, and Andean regions of Colombia, between an elevational range from 0 to 1,800 masl. The distribution covers the Peri-Caribbean Arid Belt, Chocó-Magdalena, and Nor-Andean biogeographic provinces (sensu Hernández Camacho et al. 1992). Records of $B$. medius in Colombian collections are scarce (SuárezCastro and Ramírez-Chaves 2015). Only the mammals collections of the Universidad del Valle (UV) and Universidad de Nariño (PSO-Z) have specimens of this species. Records in literature identified as B. gabbi from the Department of Cauca (Rivas-Pava et al. 2007) and other two specimens deposited in the collection of mammals of the Museum of Natural History at Universidad del Cauca (without exact locality), belong to $B$. neblina. Considering the scarcity of records of $B$. medius in Colombian collections, nit is worth highlighting the rescue of the skull (CZUC-M-0246) for its deposit in a biological collection.

Finally, although specimens of other procyonids such as Potos flavus and Nasuella olivacea have been reported as pets (Ramírez-Chaves et al. 2008), this use in olingos is documented here for the first time. Apart of the illegal traffic, Bassaricyon are also affected byroad-kills (Delgado-Velez 2014).

\section{Acknowledgments}

HRC thanks the Facultad de Ciencias Exactas y Naturales, Universidad de Caldas for the support provided to visit the Museo de Historia Natural de la Universidad del Cauca (MHNUC). Hugo Mantilla-Meluk and an anonymous reviewer made valuable contributions to earlier versions of this manuscript. Thanks also to Pilar Rivas Pava (MHNUC), and to Bruce D. Patterson and The Science and Scholarship Committee of the Field Museum of Natural History, Chicago, for allowing the review of specimens under their care. María Elena Sánchez-Salazar translated the manuscript into English.

\section{Literature Cited}

Alberico, M., A. Cadena, J. Hernández-Camacho, and Y. Muñoz-Saba. 2000. Mamíferos (Synapsida: Theria) de Colombia. Biota Colombiana 1:43-75.

Arteaga, T. M. 2014. Condiciones ambientales del humedal de Sierra Chiquita, municipio de Montería. Tesis de Maestría en Desarrollo Sostenible y Medio Ambiente. Universidad de Manizales. Manizales, Colombia.

Andrade-Ponce, G. P., J. S. Jiménez-Ramírez, S. M. MontañoSalazar, and L. M. Riveros-Loaiza. 2015. Generalidades del orden Carnivora. Pp. 23-25 in Los carnívoros terrestres y semiacuáticos continentales de Colombia. Guía de campo (Suárez-Castro, A. F., and H. E. Ramírez-Chaves, eds). Editorial Universidad Nacional de Colombia. Bogotá, Colombia.

Andrade-Ponce, G. P., S. M. Montaño-Salazar, L. M. Riveros-Loaiza, H. E. Ramírez-Chaves, and A. F. Suárez-Castro. 2016. Estado del conocimiento y prioridades de investigación sobre las familias Canidae, Mephitidae y Procyonidae (Mammalia: Carnivora) en Colombia. Revista de la Academia Colombiana de Ciencias Exactas, Físicas y Naturales 40:500-513.
Cardona, D., F. L. Meza-Joya, and J. Colmenares. 2016. New Olingo records (genus Bassaricyon) from the Colombian Andes. Small Carnivore Conservation 54:12-18.

Delgado-Vélez, C. A. 2014. Adiciones al atropellamiento vehicular de mamíferos en la vía de El Escobero, Envigado (Antioquia). Revista EIA 11:147-153.

Díaz-Pulido, A., A. Benítez, D. Gómez-Ruiz, C. Calderón-Acevedo, A. Link, A. Pardo, F. Forero, G. De Luna, E. Payán, and S. Solari. 2014. Mamíferos del bosque seco: una mirada al Caribe colombiano. Pp. 128-165 in El bosque seco tropical en Colombia (Pizano, C., and H. García, eds.). Instituto de Investigación de Recursos Biológicos Alexander von Humboldt (IAvH). Bogotá, Colombia.

Emmons, L. H., and F. Feer. 1990. Neotropical rainforest mammals: A field guide. University of Chicago Press. Chicago, U. S. A.

Gerstner, B. E., J. M. Kass, R. Kays, K. M. Helgen, and R. P. Anderson. 2018. Revised distributional estimates for the recently discovered olinguito (Bassaricyon neblina), with comments on natural and taxonomic history. Journal of Mammalogy 99:321-332.

Goldman, E. A. 1912. New mammals from eastern Panama. Smithsonian Miscellaneous Collections 60:1-18.

GonzÁlez-MayA, J. F., and J. L. Belant. 2010. Range extension and sociality of bushy-tailed olingo Bassaricyon gabbii in Costa Rica. Small Carnivore Conservation 43:37-39.

GuZMán-LenIS, A. R. 2004. Revisión preliminar de la familia Procyonidae en Colombia. Acta Biológica Colombiana 9:69-76. Helgen, K. M., C. M. Pinto, R. Kays, L. E. Helgen, M. T. Tsuchiya, A. Quinn, D. E. Wilson, and J. E. Maldonado. 2013. Taxonomic revision of the olingos (Bassaricyon), with description of a new species, the Olinguito. ZooKeys 324:1-83.

Helgen, K., R. Kays, C. Pinto, and J. Schipper. 2016. Bassaricyon medius in IUCN 2017. The IUCN Red List of Threatened Species. Version 2017.3 www.iucnredlist.org. Consultado el 05 de octubre 2018.

Hernández Camacho, J. I., A. H. Guerra, R. O. Quijano, and T. WalsChBURGER. 1992. Unidades biogeográficas de Colombia. Pp. 105-151 in La diversidad biológica de Iberoamérica. Vol. I (Halfer, G. Ed.). Acta Zoológica Mexicana, Nueva Serie, Vol. Especial. Ciudad de México, México.

Muñoz, Y., y M. Hoyos-R. 2012. Los mamíferos del Caribe colombiano. Pp. 703-721 in Colombia Diversidad Biótica XII. La región Caribe de Colombia (Rangel-Ch, J. O. Ed.). Universidad Nacional de Colombia, Instituto de Ciencias Naturales. Bogotá, Colombia.

Racero-Casarrubia, J., J. Ballesteros-Correa, and J. Pérez-Torres. 2015. Mamíferos del departamento de Córdoba-Colombia: historia y estado de conservación. Biota Colombiana 16:128148.

Ramírez, A., and F. Valencia. 2007. Guía de identificación de fauna silvestre. Área Metropolitana del Valle de Aburra, Medellín. Antioquia, Colombia.

ReID, F. A. 1998. A field guide to the mammals of Central America and Southeast Mexico. Oxford University Press, New York. New York, U. S. A.

Ramírez-Chaves, H. E., W. Pérez, and J. Ramírez Mosquera. 2008. Mamíferos presentes en el municipio de Popayán, CaucaColombia. Boletín Científico, Centro de Museos, Museo de Historia Natural, Universidad de Caldas 12:65-89. 
Ramírez-Chaves, H. E., and E. A. Noguera-Urbano. 2010. Lista preliminar de los mamíferos (Mammalia: Theria) del Departamento de Nariño - Colombia. Biota Colombiana 11:115-138.

Ramírez-Chaves, H. E., A. F. SuÁrez-Castro, and J. F. González-Maya. 2016. Cambios recientes a la lista de los mamíferos de Colombia. Mammalogy Notes 3:1-9.

Rivas-Pava, P., H. E. Ramírez-Chaves, Z. Álvarez, and B. L. NiñoValencia. 2007. Catálogo de los Mamíferos presentes en las colecciones de referencia y exhibición del Museo de Historia Natural de la Universidad del Cauca. Taller Editorial Universidad del Cauca. Popayán, Colombia.

SaAvedra-Rodríguez, C. A., and J. H. Velandia-Perilla. 2011. Bassaricyon gabbii Allen, 1876 (Carnivora: Procyonidae): New distribution point on western range of Colombian Andes. Check List 7:505-507.

Solari, S., Y. Muñoz-Saba, J. V. Rodríguez-Mahecha, T. R. Defler, H. E. Ramírez-Chaves, and F. Trujillo. 2013. Riqueza, endemismo y conservación de los mamíferos de Colombia. Mastozoología Neotropical 20:301-365.

SuÁrez-Castro, A. F., and H. E. Ramírez-Chaves. 2015. Los carnívoros terrestres y semiacuáticos continentales de Colombia. Guía de campo. Editorial Universidad Nacional de Colombia. Bogotá, Colombia.

Thomas, O. 1909. Notes on some South American mammals, with descriptions of new species. Annals and Magazine of Natural History 4:230-242.

Associated editor: Robert Owen

Submitted: October 4, 2018; Reviewed: January 18, 2019;

Accepted: January 29, 2019; Published on line: March 21, 2019. 
206 THERYA Vol. 10 (2):201-205 